\title{
THE INFLUENCE OF SOCIAL DISTANCE IN THE USE OF REQUEST STRATEGIES IN THE PROPOSAL MOVIE
}

\author{
Flora Debora Floris, Veronica Noviyanti Loanata
}

\begin{tabular}{c} 
Email: debora@peter.petra.ac.id \\
Fakultas Sastra Universitas Kristen Petra Surabaya \\
Alamat Koresponden: Jalan Siwalankerto 121-131 Surabaya \\
\hline
\end{tabular}

\begin{abstract}
Request is a face-threatening act (FTA) that requires the ability of the speaker not only in the language itself, but also in applying the language used in its context. One of the social dimensions, named social distance, proposed by Holmes (2001), is found to be given its influence in the use of request. In this study, the writers wanted to know about request strategies spoken by Margaret Tate (a leader) to Andrew Paxton (her assistant) before and after their contract marriage, as seen in The Proposal movie. The writer used qualitative approach supported by quantitative data. The findings of this research show that in general, there are some similarities and differences of the use of request strategies before as well as after the contract marriage. In general, it can be assumed that Margaret's higher social status is giving more influences to the requests spoken to Andrew rather than the social distance itself.
\end{abstract}

\section{Keywords}

Request, Request Strategies, Social Distance

\section{Introduction}

According to Trosborg (1994, p. 187), request is an illocutionary act whereby a speaker (requester) conveys to a hearer (requestee) that he or she wants the requestee to perform an act, which is for the benefit of the speaker. Moreover, the function or purpose of request is to involve the hearer in some future actions, which have positive consequences for the speaker (p. 15).

Request is one of the essential linguistic topics to analyze since it is defined as a face-threatening act (FTA) that requires the ability of the speaker not only in the language itself, but also in applying the language used in its context. Significantly, in order to make a request, people have to be careful because it can be considered something that burdens the addressee. Besides, the requester also runs the risk of losing face him or herself, as the requestee (the hearer) may choose to refuse to comply with his or her wishes (p. 188). Therefore, a speaker needs to apply the appropriate strategy to convey what he or she wants to say to the hearer.

There are ten request strategies proposed by Trosborg (1991, p. 76 and 1994, pp. 192-204) as seen in the following figure1. 


\section{Conclusion}

This research is only a small scale of research, which only used a movie as its source of data and paid attention only to one social variable, named social distance. Therefore, the writers recommend other researchers to conduct further studies about requests, for example by involving more social variables, such as gender, social status, age, and etcetera. The further studies might also be more interesting if the researchers use more movies as the source of data. It is because movies can be a good media to learn some linguistic features. Besides, the other researchers can also conduct a further study about requests which compares verbal requests and non-verbal requests (for instance a request stated by making an eye contact).

\section{REFERENCES}

Aijmer, K. 1996. Conversational Routines in English: Convention and Creativity. London: Longman

Blum-Kulka, S., House, J., and Kasper, G. (Eds). 1989. Cross-Cultural Pragmatics: Requests and Apologies. Norwood, New Jersey: Ablex Publishing Corporation.

Holmes, J. 2001. An Introduction to Sociolinguistic. Harlow: Longman.

Marquez-Reiter, R. 2000. Linguistic Politeness in Britain and Uruguay: A Contrastive Study of Requests and Apologies. Amsterdam: John Benjamin Publishing Co.

Oentoro, G. D. 2006. The Request Strategies Used by The Male Superior and The Female Subordinate Before and After Having Close Relationship in The Film "Two Weeks Notice". Unpublished undergraduate thesis. Petra Christian University, Surabaya.

Trosborg, A. 1991. An Analysis of Legal Speech Acts in English Contract Law. Hermes, Journal of Linguistics, (6), 65-90.

1994. Interlanguage pragmatics: Requests, Complaints and Apologies. Berlin: Mounton de Gruyter.

Tsui, A. B. M. 1994. English Conversation. Oxford: Oxford University Press. 